Brit. J. vener. Dis. (1962), 38, 167

\title{
MEDICAL SOCIETY FOR THE STUDY OF
}

\author{
THE VENEREAL DISEASES
}

The Edinburgh Meeting, 1962

A gratifying number of members of the Society made the journey to Edinburgh and listened to the most interesting accounts by two colleagues who had undertaken a much longer journey to learn something of the management of venereal diseases in the U.S.S.R. Dr. Marjorie Murrell, Chairman of the Scottish Branch of the M.S.S.V.D., gave a cordial welcome to the Society on its first raid over the Border, and hoped they would take away pleasant memories of a profitable meeting.

The President then called on Dr. Willcox and Mr. King to read their papers, from which we learned that the Russians have spared no expense in equipping clinics and in employing very numerous medical and para-medical personnel to treat venereal disease. Popular education on the subject is carried out on a scale greater than in the United Kingdom, or indeed in any other country, and it is taught that to transmit infection is anti-social conduct. What measure of success is attending these vast efforts time will, or perhaps will not, tell. Members much enjoyed the colour slides taken by Mr. King when in Russia.

The only other business at this meeting, held in the Royal Infirmary, was a short account, given by Dr. Scott-Gray, of three unusual clinical cases, two of them being that now very rare condition, gonococcal septicaemia.

Of the social occasions that followed, graced by the presence of the wives of many of the members, much could be written and even then we should not have said enough by way of thanks to our Scottish hosts. The reception given by Dr. and Mrs. Robert Lees at their delightful home, the tours of ancient Edinburgh and of the countryside, and finally the Dinner, all ensured that new acquaintances would be made and old ones not forgotten. It was a special pleasure to see among the large company two of our most senior members, Dr. Nora Wattie, for many years the Secretary of the Scottish Branch, and Dr. Ralph Batchelor, who was looking as hale and hearty as ever in his retirement. "The Health of the Society" was responded to with acclamation. The proposer had referred to venereal disease in World War I, and Dr. Lees-not to be outdone-took us back to the Boer War before giving us the toast of "Our Guests". The Society was honoured by the genial presence of Dr. Seiler, Medical Officer of Health of Edinburgh, and of Professor Robert Cruickshank, well-known to London members when he occupied the Chair of Bacteriology at St. Mary's Hospital before his translation to Edinburgh. In replying to the toast, Professor Cruickshank maintained that his speciality owed much to the venereologists, for its status had risen remarkably along with the development of that branch of medicine in which his hosts of the evening were recognized authorities. He finished, as a good Scot, with a reference to the Bible; but, like the earlier speakers, he did not err on the side of undue solemnity. It was in Paris last year that someone remarked "I never knew that venereologists could be so human!" In that respect, and in others also, the Scottish capital was on a par with the French. Our one regret was that no member from France was able to be with us on this occasion.

Some of the Sassenachs were a trifle surprised to find so little evidence of Scottish nationalism or of presbyterian piety - the lion rampant appeared to be couchant-until at the Dinner the Treasurer stood up and said grace in the words of Robert Burns. We had to leave before the end, and so we do not know whether the last item on the agenda was the Benediction or Auld Lang Syne: but we do know that many of the company blessed the planners of this "out-oftown" meeting in the fair city of Edinburgh, and vowed to meet again some other night-perhaps next June, in beautiful Copenhagen.
R.F. 